\title{
Effect of Treatment Compositions on the Plasticity of Tropical Red Soil Treated with Bacillus Coagulans.
}

\author{
Paul Yohanna ${ }^{1 *}$, Kolawole Juwonlo Osinubi ${ }^{2}$, Oshioname Adrian Eberemu ${ }^{2}$, Thomas \\ Stephen Ijimdiya ${ }^{2}$, John Engbonye Sani ${ }^{3}$ \\ 1. Department of Civil Engineering, University of Jos, Jos, 930001, Plateau State, Nigeria \\ 2. Department of Civil Engineering, Ahmadu Bello University Zaria, 810001, Kaduna State, Nigeria \\ 3. Department of Civil Engineering, Faculty of Engineering, Nigeria Defence Academy, Kaduna, Nigeria \\ E-mail: paulyohanna45@yahoo.co.uk (Corresponding author)
}

Received: 28 December 2021; Accepted: 21 January 2022; Available online: 10 February 2022

\begin{abstract}
The study evaluated the effect of four treatment compositions on the plasticity of tropical red soil (Lateritic soil) admixed with Bacillus coagulans (B. coagulans). Samples for Atterberg limits test were prepared using four treatment compositional variables. They include $25 \%$ B. coagulans suspension and $75 \%$ cementation reagent, $(25 \% \mathrm{~B} / 75 \% \mathrm{C}) ; 50 \%$ B. coagulans suspension and 50\% cementation reagent (50\% B /50\%C); $75 \% \mathrm{~B}$. coagulans suspension and $25 \%$ cementation reagent, $(75 \% \mathrm{~B} / 25 \% \mathrm{C})$ with the above three being in equivalent volumes of the corresponding liquid limit(LL) and $50 \%$ of the optimum moisture content (OMC) of compaction, to be both B. coagulans suspension and cementation reagent (i.e. 50\% OMC B $/ 50 \% \mathrm{OMC}$ C) of the natural soil. Results showed that the LL for; $25 \% \mathrm{~B} / 75 \%$ C, $50 \%$ B $/ 50 \%$ C and 75\% B /25\%C generally increased from 0 up to peak values at $1.8 \times 10^{9}$ cells $/ \mathrm{ml}$ and then declined at $2.4 \times 10^{9}$ cells $/ \mathrm{ml}$. In the case of samples treated with $50 \%$ OMC B/50\% OMC C, the LL initially decreased from 0 up to $6.0 \times 10^{8}$ cells/ml and thereafter increased significantly. Plastic limit (PL), Plasticity index (PI) and Linear shrinkage (LS), recorded improvement. Regression analysis for the best treatment composition (i.e $75 \% \mathrm{~B} / 25 \% \mathrm{C}$ ) has regression coefficient of $91.8 \%$. Based on the four treatment compositions considered, $75 \% \mathrm{~B} / 25 \% \mathrm{C}$ enhanced the soil workability significantly and is suggested for geotechnical engineering applications such as road pavements that are lightly trafficked.
\end{abstract}

Keywords: Atterberg limit; B. coagulans; Cementation reagent; Lateritic soil; Micro analysis; Regression.

\section{Introduction}

Lateritic soil is a reddish tropical soil found in abundance in Nigeria which in most case is not fit for usage as construction material in its natural form due to high fines content, high water absorption, swelling and shrinkage problems during wetting and drying and so on. Many of such soils are deficient for engineering applications and hence need improvement prior to field application. Past researches [1-4] used well known additives such as cement, agro-industrial waste, lime, and other pozzolanic materials for soil improvement. These practices are either more expensive or some of them are not ecologically pleasant and therefore not viable as a means for soil improvement.

Over the years, several techniques of soil improvement have emerged to enhance engineering properties of deficient soils. Van Paassen [5] first reported on a research in Australia someplace bacteria were utilized to reinforce sand and repair monuments. However, further investigations by Australian research group reported that after treatment with bacteria suspension, the sand turned to columns of calcareous sandstone [6]. The bio-cemented columns of sand were then broadly analyzed and recorded a decline in permeability and increase in strengths. This finding gave rise to microbial-induced calcite precipitation (MICP). MICP is a new sustainable and environmentally friendly soil improvement procedure that makes the use of soil micro- organisms (such as $B$. coagulans) to precipitate calcite through urea hydrolysis.

Report of research by Burne and Chen [7] on urea hydrolysis involves a sequence of chemical reactions (see eqs. (1) - (6)) that end result is the formation of ammonium and carbon dioxide. The role of microbes (i.e $B$. coagulans) is the release of urease enzymes that activate the urea hydrolysis needed for the bio-cementation and bio-clogging of the treated soil. The chemical reaction of urea hydrolysis is shown in eq. (1):

$$
\mathrm{CO}\left(\mathrm{NH}_{2}\right)_{2}+\mathrm{H}_{2} \mathrm{O}=2 \mathrm{NH}_{3}+\mathrm{CO}_{2}
$$


The produced hydroxyl ions obtained as by product of ammonia conversion to ammonium results in the rise in $\mathrm{pH}$ value which pave way for bicarbonate decomposition to form carbonate ions as shown in eq (2):

$$
2 \mathrm{NH}_{3}+2 \mathrm{H}_{2} \mathrm{O}=2 \mathrm{NH}_{4}^{+}+2 \mathrm{OH}^{-}
$$

The carbon dioxide produced further decomposes to bicarbonate $\left(\mathrm{HCO}_{3}\right)$ in the presence of water (see eq. (3)) and it thus reacts with the hydroxyl ions to produce carbonate ions (see eq. (4)) and henceforth in calcium ion $\left(\mathrm{Ca}^{2+}\right)$ presence, the calcite $\left(\mathrm{CaCO}_{3}\right)$ is precipitated (see eq. (5))

$$
\begin{aligned}
& \mathrm{CO}_{2}+\mathrm{H}_{2} \mathrm{O}=\mathrm{HCO}_{3}^{-}+\mathrm{H}^{+} \\
& \mathrm{HCO}_{3}^{-}+\mathrm{H}^{+}+2 \mathrm{OH}^{-}=\mathrm{CO}_{3}^{2-}+2 \mathrm{H}_{2} \mathrm{O}
\end{aligned}
$$

Equations 3 and 4 shows that

$$
\mathrm{Ca}^{2+}+\mathrm{CO}_{3}^{2-}=\mathrm{CaCO}_{3}
$$

The complete process for the urea hydrolysis and the corresponding calcium carbonate formation is represented in eq. (6)

$$
\mathrm{CO}\left(\mathrm{NH}_{2}\right)_{2}+2 \mathrm{H}_{2} \mathrm{O}+\mathrm{Ca}^{2+}=2 \mathrm{NH}_{4}^{+}+\mathrm{CaCO}_{3}
$$

Bio-clogging and Bio-cementation are the two notable applications among many in MICP. Bio-clogging is a process that involves the lessening of the hydraulic conductivity of soil and porous rocks by a materials pore filling the soil void, produced by microbial activity [8]. On the other hand, Bio-cementation improves the workability, strength and the corresponding stiffness of soil and rocks via microbial activity [9]. Bio-cementation involves formation of particle binding material via microbial enzymatic activities which result to improvement in the stiffness and strength of the treated soil [10]. MICP successfully increased the stiffness and strength and also reduced the water permeability of soils as reported in related literatures [11-17]. This study is aimed at evaluating the effect of soil microbes (B. coagulans) on the plasticity of treated lateritic soil using different Treatment Compositions.

\section{Materials and methods}

\subsection{Materials}

1) Soil sample. Lateritic soil used was sourced from Abagana (68'24’31'’ N and 27052'11'’E), Anambra state, Nigeria. Sample was collected by disturbed sampling technique.

2) Microorganism. The B. coagulans known to be a urease positive bacteria was use for the study. The microbe was isolated from the soil.

3) Cementation reagent. The composition of cementitious reagent used for the study is as outlined by StocksFischer et al., [18]. It contains $2.8 \mathrm{~g} \mathrm{CaCl}_{2}, 20 \mathrm{~g}$ of urea, $3 \mathrm{~g}$ of Nutrient broth, $10 \mathrm{~g}$ of $\mathrm{NH}_{4} \mathrm{Cl}$ and $2.12 \mathrm{~g}$ of $\mathrm{NaHCO}_{3}$ per litre of distilled water.

\subsection{Methods}

\subsubsection{Isolation of the bacterium specie}

The Microorganism (B. coagulans) was isolated from the soil by using serial dilution (In this method $1 \mathrm{~g}$ of soil measured was placed in $9 \mathrm{ml}$ of sterile distilled water in other to obtain a soil suspension, the process continues to obtain higher dilution of soil suspensions). The isolates were stored at $4^{\circ} \mathrm{C}$ temperature value in nutrient medium in preparation for its classification and characterization.

\subsubsection{The culture medium and growth conditions}

The process for preparing culture medium and growth conditions is as delineated by Stocks-Fischer et al., [18]. B. coagulans categorized by American Type Culture Collection as ATCC 8038 [19] was used throughout the study.

\subsubsection{MICP treatment procedures and methods}

Soil sample for atterberg limit test before MICP treatment was first passed through $425 \mu m$ sieve. MICP technique was performed by calculating the amount of $B$. coagulans for varying suspension densities and 
cementation reagent. Measurement of B. coagulans suspension and cementation reagent was done with the help of a syringe. Four different treatment methods were adopted.

The first three treatment methods were done relative to the liquid limit of the natural soil.The methods involved the use of:

a) $25 \%$ of liquid limit to be $B$. coagulans suspension and $75 \%$ of liquid limit to be cementation reagent, making a total of $100 \%$ liquid limit $(25 \% \mathrm{~B} / 75 \% \mathrm{C})$

b) $50 \%$ of liquid limit to be $B$. coagulans suspension and $50 \%$ of liquid limit to be cementation reagent, making a total of $100 \%$ liquid limit $(50 \% \mathrm{~B} / 50 \% \mathrm{C})$

c) $75 \%$ of liquid limit to be B. coagulans suspension and $25 \%$ of liquid limit to be cementation reagent, making a total of $100 \%$ liquid limit $(75 \%$ B $/ 25 \%$ C). Each Test was carried out in duplicate to justify the output of the experiments.

An additional method was also used to determine the atterberg limits relative to optimum moisture content (OMC) of British standard light (BSL) compaction. Compaction test was first carried out on the natural soil using BSL compaction (the most achievable compaction energy in the field) to establish the OMC of compaction. The amount of $B$. coagulans and cementation reagent used for treating the soil was computed relative to the OMC. This method was carried out by mixing the soil with $50 \%$ of OMC of compaction to be $B$. coagulans suspension and $50 \%$ of OMC of compaction to be cementation reagent (i.e. 50\% of OMC B/50\% of OMC C) making a total of $100 \%$ OMC of the natural soil.

The suspension densities of $B$. coagulans used in treating the soil for all the methods were $0,1.5 \times 10^{8}, 6.0 \times$ $10^{8}, 1.2 \times 10^{9}, 1.8 \times 10^{9}$ and $2.4 \times 10^{9} / \mathrm{ml}$, correspondingly. Treated soil specimens were air-dried at laboratory temperature of $25 \pm 2{ }^{\circ} \mathrm{C}$.

\subsubsection{Mass of calcium carbonate content (CCC) measurements}

Samples for CCC measurement were treated prior to compaction with B.coagulans suspension at one-third (1/3) pore volume (as mentioned by Rowshanbakhta et al., [20] ) in step suspension densities of the microbes. Cementitious reagent was then applied on the compacted soil until saturation was attained. Compacted samples in the mould were used for each stepped suspension density. The samples were then allowed to air dry at laboratory temperature of $25 \pm 2^{\circ} \mathrm{C}$ prior testing. The measurement procedure used is in accordance with that proposed by Mortensen et al., [21] and Choi et al., [22] called the acid wash method. This approach helps in dissolving all soluble calcium in the soil. After washing, with dilute acid, the retained soil mass is dried in an oven and weighed. The difference in the mass between the initial soil sample (A) and the retained sample after washing sample (B) is defined as calcium carbonate mass. The CCC was computed using eq. 7.

$$
C C C=100-\frac{B}{A} \times 100
$$

\subsubsection{Statistical analysis}

A statistical evaluation was carried on the measured soil variables. The variables include: Plasticity index (PI) as dependent parameter and Liquid limit (LL), Plastic limit (PL), Linear shrinkage (LS) and B. coagulans suspension (BCS) density as independent parameters. A regression model was established using Minitab R15 software to forecast the Plasticity index (PI) from the measured laboratory results.

\section{Results and discussion}

\subsection{Index properties}

The natural soil categorized as A-4(2) soil according to American Association of State Highway and Transportation Officials [23] classification system and SC soil according to Unified Soil Classification System (USCS) [24]. A summary of the properties of the natural soil is given in Table 1.

\subsection{Calcium carbonate content}

The Plot of CCC with B. coagulans suspension density is displayed in fig. 1. Plot shows that the amount of CCC formed inside the soil matrix improved with increased in the microbial population from 0/ml upto $2.4 \times 10^{9}$ cell/ml. Values marginally increased from 3.6 to 3.9\%. The increased could be related with rise in the amount of urease enzymes released by $B$. coagulans. As the number of the $B$. coagulans increased it is apparent that more urease enzymes are released by the microbes leading to the increase in the formation of the calcium carbonate. Chi et al., [12] and Osinubi et al.,[15] in there researches reported that increased microbial density results to higher enzyme activities because of the faces of the microbes serves as a nucleation site to encouraged calcite precipitation in the soil. 
Table 1. Natural soil properties

\begin{tabular}{ll}
\hline Property & Quantity \\
\hline Percentage Passing BS No. 200 Sieve & 35.4 \\
Natural Moisture Content, \% & 11.3 \\
Liquid Limit, \% & 34.4 \\
Plastic Limit, \% & 8.3 \\
Plasticity Index, \% & 26.1 \\
Linear shrinkage, \% & 8.73 \\
Specific Gravity & 2.62 \\
AASHTO Classification & A-4(2) \\
USCS & SC \\
Colour & Reddish brown \\
\hline
\end{tabular}

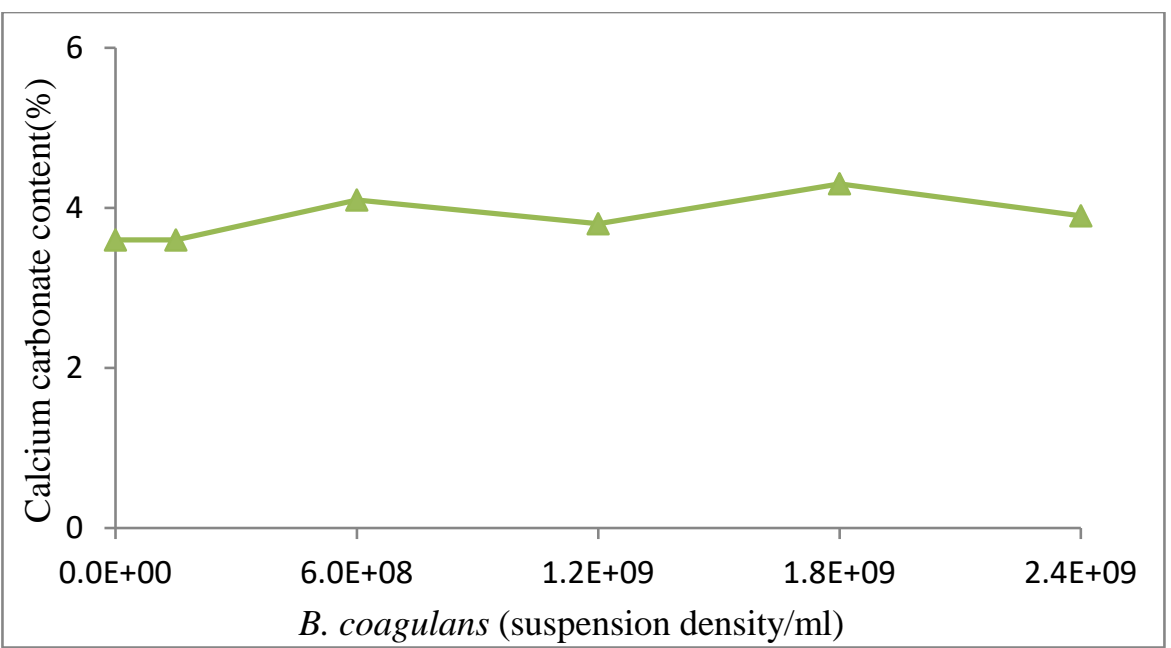

Fig. 1. Calcium carbonate content measurement with varying composition of $B$. coagulans and cementation reagent.

\subsection{Effect of B. coagulans on atterberg limit}

\subsubsection{Liquid limit}

The liquid limit for the three methods of treatment (i.e $25 \% \mathrm{~B} / 75 \% \mathrm{C}, 50 \% \mathrm{~B} / 50 \% \mathrm{C}$ and $75 \% \mathrm{~B} / 25 \% \mathrm{C}$ ) generally showed a trend of increase from 0 upto peak values at $1.8 \times 10^{9}$ cells $/ \mathrm{ml}$ and thereafter decreased at 2.4 x $10^{9}$ cells $/ \mathrm{ml}$ (see fig. 2). Values increased each from $34.4 \%$ to $36.95 \%$, $36.6 \%$ and $38 \%$ for $25 \% \mathrm{~B} / 75 \% \mathrm{C}, 50 \% \mathrm{~B}$ $150 \% \mathrm{C}$ and $75 \% \mathrm{~B} / 25 \% \mathrm{C}$, respectively. Although all the three treatment compositions recorded similar trend, $50 \% \mathrm{~B} / 50 \% \mathrm{C}$ recorded the best improvement in liquid limit follow by $25 \%$ of LL Bac/75\% of LL Cem. The variations recorded were not soo high showing that all the tree methods improved the workability of the soil. The recorded improvement could be associated with the urea hydrolysis that led to the formation of calcite that aid in stiffening of the soil. The ammonia produced as a by-product of urea hydrolysis and released into the soil could be the possible reason for increased $\mathrm{pH}$, and headed to build-up of insoluble calcium trioxocarbonate IV (CaCO3). Similar statement were made by past researches [25-26]. Sheelah [27] reported a decrease in liquid of treated lateritic soil and Kuttanad clays with Bacillus persteurii.

In the case of samples treated with $50 \%$ of OMC B/50\% of OMC C, the liquid limit initially decreased from 0 upto $6.0 \times 10^{8}$ cells/ml and thereafter increased significantly (see fig. 2). The recorded results show that $50 \%$ of $\mathrm{OMC} \mathrm{B} / 50 \%$ of OMC $C$ treatment method tends to increase swelling potential of the soil with increase in the $B$. coagulans suspension density above $6.0 \times 10^{8}$ cells $/ \mathrm{ml}$. The suggested reason could be due to other geochemical processes that occur within the soil structure such as Biofilm formation, biogas generation and the formation of other extracellular polymeric substances (EPS) may be responsible for such recorded results. However the amount B. coagulans suspension density and cementation reagent use for treating the soil before drying, which is related to the OMC of compaction cannot be under estimated as a factor for such behavior.

\subsubsection{Plastic limit}

The graph of plastic limit against B.coagulans suspension density for all the treatment compositions used is shown in fig. 3. It was noticed from the results that the plastic limit generally increased for all the treatment methods with exception of some few points. Samples treated with $25 \%$ B /75\%C, $50 \%$ B /50\%C and 75\%B /25\%C, 
respectively, showed marginal differences in their plastic limit values. Values increased each from the natural value of $8.3 \%$ to 24.42 , 23.17 and $17.32 \%$ at $2.4 \times 10^{9}$ cells $/ \mathrm{ml}$ for $25 \% \mathrm{~B} / 75 \% \mathrm{C}, 50 \% \mathrm{~B} / 50 \% \mathrm{C}$ and $75 \% \mathrm{~B} / 25 \% \mathrm{C}$ respectively. The increase in plastic limit may be due to $B$. coagulans urease hydrolysis of urea which formed inorganic carbon and also dissolved ammonium as well as carbon dioxide $\left(\mathrm{CO}_{2}\right)$. The ammonia formed and freed into the soil specimens increased the $\mathrm{pH}$ thus resulting in the buildup of insoluble calcium trioxocarbonate IV $\left(\mathrm{CaCO}_{3}\right)$ [27].

In the case of samples treated with $50 \%$ of OMC B/50\% of OMC C, similar trend of increase was noted with rise in $B$. coagulans suspension density. Value increased from $8.3 \%$ to $17.32 \%$. Based on the recorded results for all the methods used, $50 \%$ of OMC B/50\% of OMC C recorded the least plastic limit values.This suggested the importance of the treatment composition on the plasticity of lateritic soil treated with $B$. coagulans suspension density. Therefore proper attention is required on treatment composition during field application to achieve the desired workability.

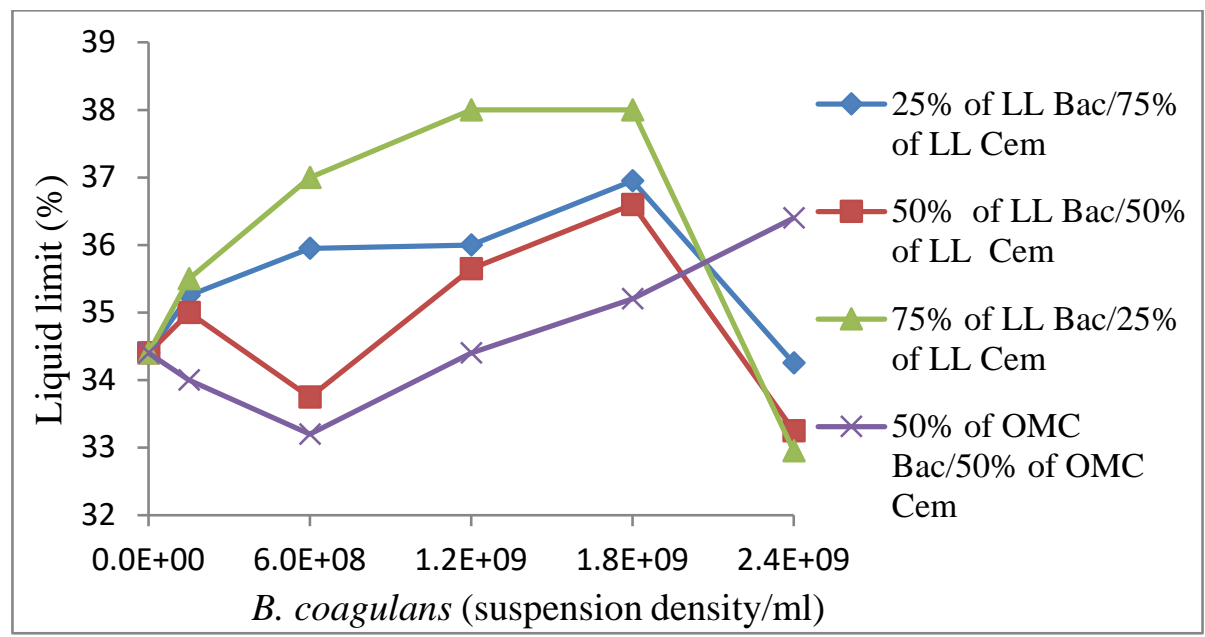

Fig. 2. Liquid limit for samples treated with varying composition of B. coagulans and cementation reagent.

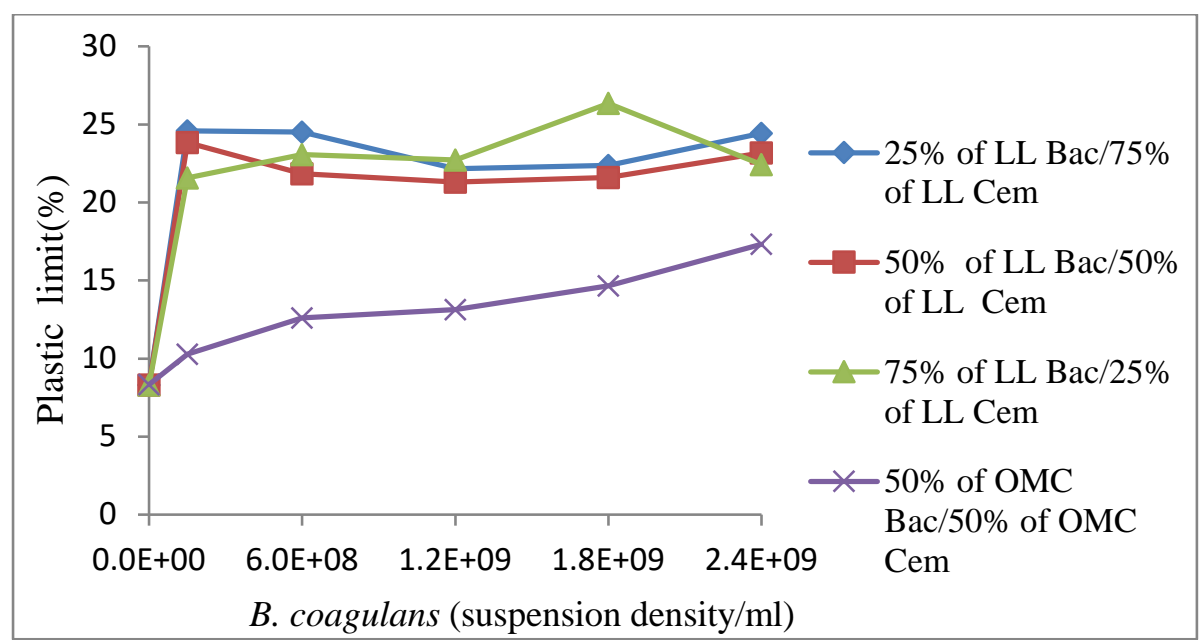

Fig. 3. Plastic limit for samples treated with varying composition of B. coagulans and cementation reagent.

\subsubsection{Plasticity index}

Fig. 4 shows a plot of plasticity index against B.coagulans suspension density for all the treatment compositions and methods used (i.e 25\%B /75\%C, 50\%B /50\%C, 75\%B /25\%C and 50\% of OMC B/50\% of OMC C). The plasticity index generally decreased for samples treated with $75 \% \mathrm{~B} / 25 \% \mathrm{C}$ and $50 \%$ of OMC B/50\% of OMC C. The decrease could probably be due to increase in the quantity of urease positive enzymes released within the soil matrix for possible calcite formation by $B$. coagulans that caused the decrease in the plasticity of the soils. Similar results was observed and reported by Osinubi et al., [28] who worked with B. Pumilus reported a fall in plasticity index with rise in B. Pumilus suspension density. Also, Sheelah [27] reported a reduction in plasticity index with increased B. pasteurii in improvement of cohesive soils. Other factors that could not be ruled out for the decrease in plasticity index is the geochemical processes that usually occur within the soil structure such as Biofilm 
formation, biogas generation and the formation of Bioplymers and other extracellular polymeric substances (EPS) may be responsible for such recorded results [15, 29-31].

The modified soil with both $25 \% \mathrm{~B} / 75 \% \mathrm{C}$ and $50 \% \mathrm{~B} / 50 \% \mathrm{C}$ showed an initial decrease in plasticity index from $0 / \mathrm{ml}$ upto $1.5 \times 10^{8}$ cells $/ \mathrm{ml}$ and thereafter increased up to $2.4 \times 10^{9}$ cells $/ \mathrm{ml}$.Values initially decreased each from the natural value of $26.1 \%$ to 10.67 and $11.17 \%$ at $1.5 \times 10^{8}$ cells $/ \mathrm{ml}$ and thereafter increased to 14.57 and $15 \%$ at $1.8 \times 10^{9} \mathrm{cells} / \mathrm{ml}$ for $25 \% \mathrm{~B} / 75 \% \mathrm{C}$ and $50 \% \mathrm{~B} / 50 \% \mathrm{C}$ respectively. The later increase in plasticity suggests increase in the swelling potential of the soil with this composition of B.coagulans and cementation reagent. This negate its suitability for pavement application such as subbase or base material. Increase in calcite formed within the soil matrix alone side biochemical reaction in the soil may be responsible for such alterations in the engineering performance of the soil.

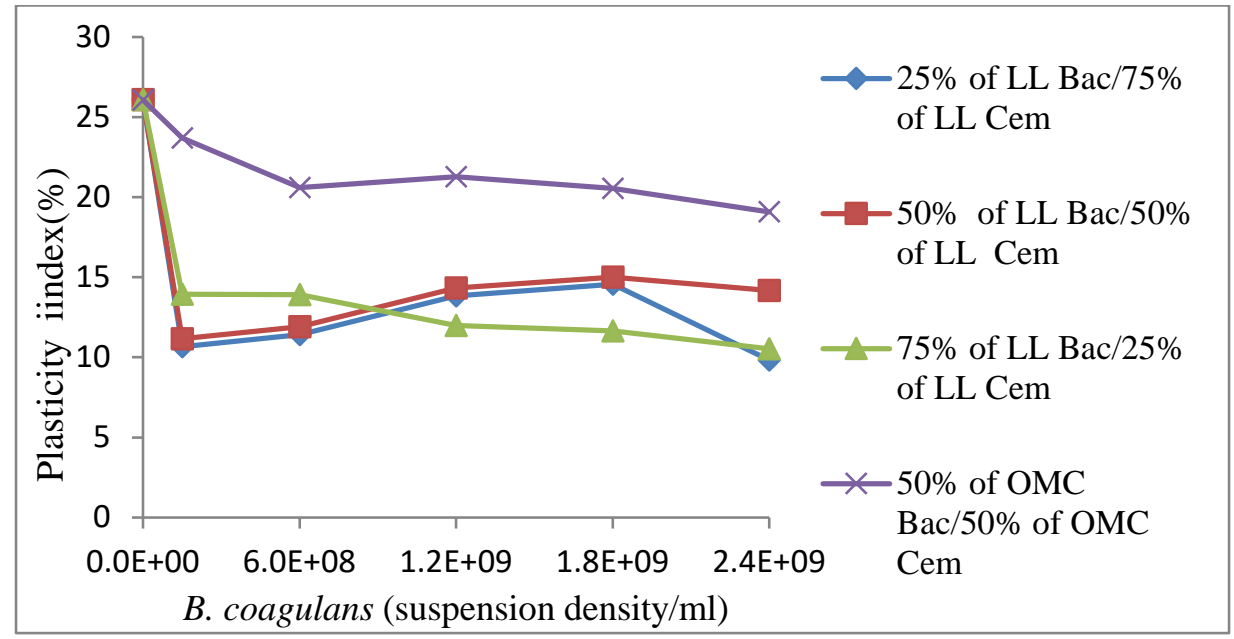

Fig. 4. Plasticity index for samples treated with varying composition of B. coagulans and cementation reagent.

\subsection{Linear shrinkage}

The linear shrinkage for all treatment compositions and methods generally showed a trend of decrease from 0 upto $2.4 \times 10^{9}$ cells $/ \mathrm{ml}$ as displayed in fig. 5. Values decreased from the natural value of $8.73 \%$ to 3.77, 5.85, 6.56 and $7.23 \%$ for $25 \% \mathrm{~B} / 75 \% \mathrm{C}, 50 \% \mathrm{~B} / 50 \% \mathrm{C}, 75 \% \mathrm{~B} / 25 \% \mathrm{C}$ and $50 \%$ of OMC B/50\% of OMC C respectively. The possible explanation to such results possibly will be due to $B$. coagulans urease hydrolysis of urea which formed inorganic carbon, carbon dioxide $\left(\mathrm{CO}_{2}\right)$ as well as dissolved ammonium. The ammonia produced and free into the soil specimens could be responsible for the rise in the $\mathrm{pH}$ thus resulting in the buildup of insoluble calcium trioxocarbonate IV $\left(\mathrm{CaCO}_{3}\right)$ [25].

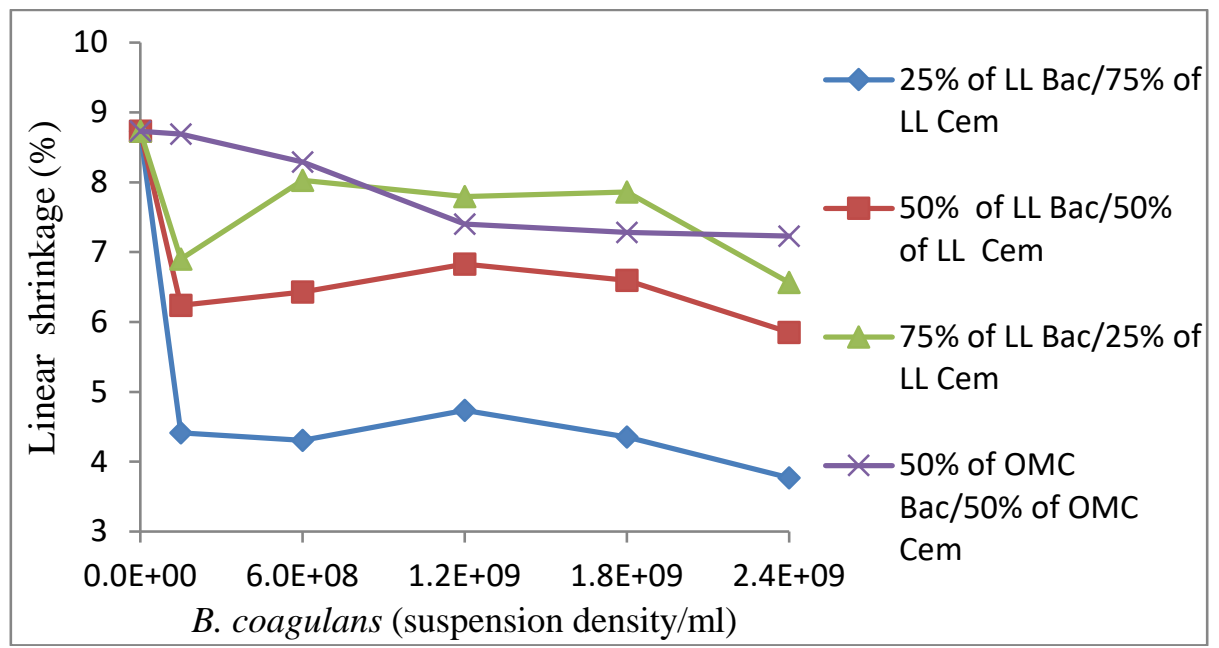

Fig. 5. Linear shrinkage for samples treated with varying composition of B. coagulans and cementation reagent.

\subsection{Regression analysis}

The regression model was developed for specimen treated with $75 \% \mathrm{~B} / 25 \% \mathrm{C}$ which gave the best improvement based on laboratory experiments among the four methods. The conceptual model established for plasticity index 
(PI) by means of Minitab R15 software (see eq. 8) illustrates a strong association between the measured laboratory PI values gotten in the laboratory and the estimated values from the regression model with correlation coefficient $\mathrm{R}=0.9841$ (see fig. 6) and 0.852-9.316\% absolute error (see Table 2). The individual influence of each of the selfdetermining variables (B. coagulans suspension(BCS ), Liquid limit(LL), Plastic limit(PL) and Linear shrinkage(LS)) provided the essential data used in developing the model for predicting PI. The established model shows strong relationship between the dependent and independent variables with regression coefficient value of 91.8\%.

All the independent variables considered have negative coefficient except LS with positive coefficient. This implies that as the other variables increased (i.e BCS, LL and PL), the PI decreased. In the case of LS, increase in LS leads to increase in PI of the soil. The implications of this regression model show that increase in LS values directly escalate the swelling potential of the soil evident by the increase in the PI with this factor. Field application of this results should ensure that the shrinkage of the treated specimens are properly guided to achieved anticipated result in the field.

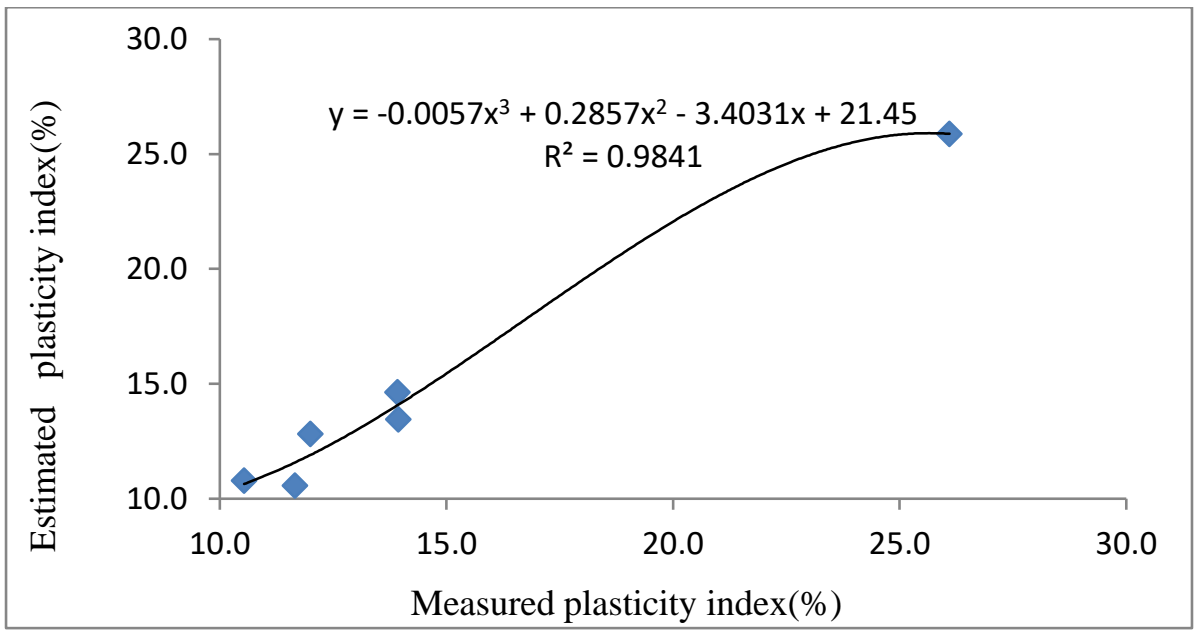

Fig. 6. Plot of estimated plasticity index against laboratory measured plasticity index values

$$
\begin{aligned}
& \mathrm{PI}=23.91-1.21 \times 10^{-9} \mathrm{BCS}-0.57 \mathrm{LL}-0.47 \mathrm{PL}+2.93 \mathrm{LS} \\
& \mathrm{R}^{2}=91.8 \%
\end{aligned}
$$

where, $\mathrm{Pl}=$ Plasticity index, $\mathrm{BCS}=$ B. coagulans suspension, $\mathrm{LL}=$ Liquid limit, $\mathrm{PL}=$ Plastic limit, $\mathrm{LS}=\mathrm{Linear}$ shrinkage.

Table 2. Estimated plasticity index against laboratory measured plasticity index values

\begin{tabular}{lllll}
\hline $\begin{array}{l}\text { B. coagulans } \\
\text { (suspension density/ml) }\end{array}$ & $\begin{array}{l}\text { Measured plasticity } \\
\text { index (\%) }\end{array}$ & $\begin{array}{l}\text { Estimated plasticity } \\
\text { index (\%) }\end{array}$ & $\begin{array}{l}\text { Absolute residual } \\
\text { error }\end{array}$ & $\begin{array}{l}\text { Error } \\
(\%)\end{array}$ \\
\hline $0.00 \mathrm{E}+00$ & 26.100 & 25.878 & 0.222 & 0.852 \\
$1.50 \mathrm{E}+08$ & 13.939 & 13.460 & 0.480 & 3.441 \\
$6.00 \mathrm{E}+08$ & 13.925 & 14.634 & 0.709 & 5.091 \\
$1.20 \mathrm{E}+09$ & 12.000 & 12.824 & 0.824 & 6.864 \\
$1.80 \mathrm{E}+09$ & 11.660 & 10.574 & 1.086 & 9.316 \\
$2.40 \mathrm{E}+09$ & 10.535 & 10.791 & 0.256 & 2.426 \\
\hline
\end{tabular}

\subsection{Micro analysis}

Micro analysis shows the changes in the morphology of the specimen viewed under microscope. Micro analysis was done for natural and $75 \% \mathrm{~B} / 25 \% \mathrm{C}$ which gave the best improvement based on laboratory experiments among the four treatment compositions. The Micrograph of natural soil and optimally treated lateritic soil with $2.4 \times$ $10 \% / \mathrm{ml} \mathrm{B}$. coagulans suspension density is shown in figs 7 and 8 respectively. It can be seen that the micrograph of natural soil has a floppy and flaccid appearance with black patches which indicate voids or micro pores within the soil skeleton as shown in fig 7. In the case of fig 8 for the modified soil, it appears to be coarser in appearance when related with the natural soil. Suggested explanation can be said to be due to bio cementation and bio clogging of the soil with $B$. coagulans suspension. B. coagulans suspension introduced into soil paved way for calcite formation by urea hydrolysis aided by the urease enzyme released by the microbes. Apart from calcite formation, 
other biogeochemical processes could be responsible for the filling of the voids within the soil matrix and stiffening of the soil as proposed by past researches [29-31].

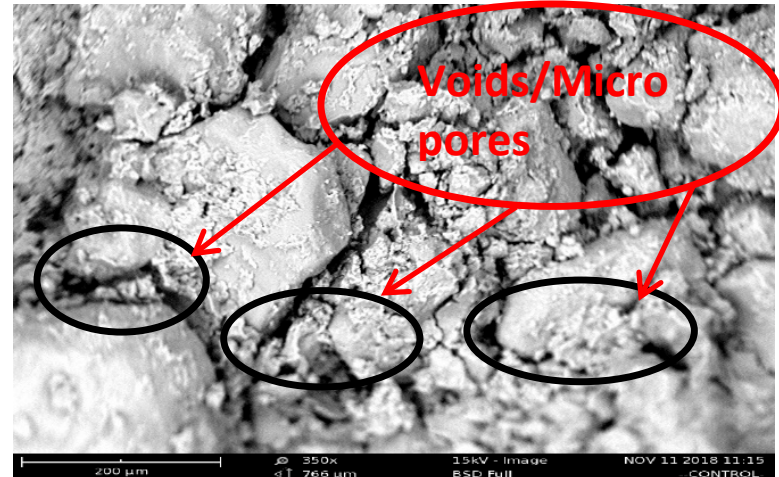

Fig.7. Micrograph of lateritic soil - 0/ml (i.e natural soil) B. coagulans suspension

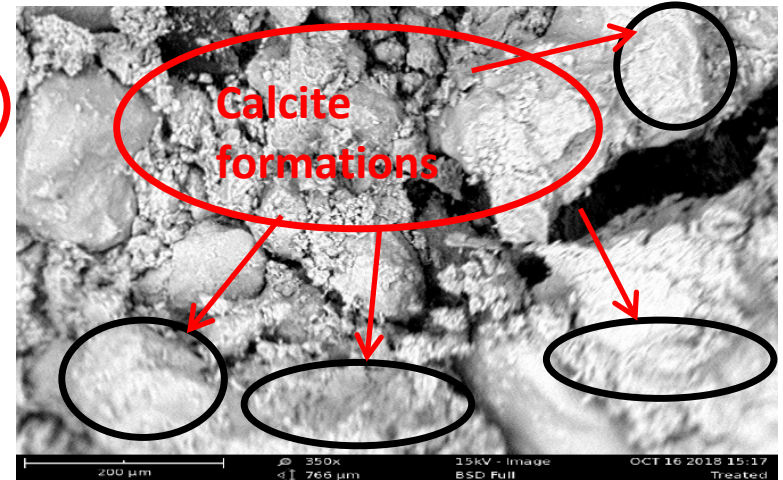

Fig.8. Micrograph of lateritic soil $-2.4 \times 10^{9} / \mathrm{ml} B$. coagulans suspension

\section{Conclusion}

The natural soil classified as A-4(2) based on AASHTO classification system and SC soil based USCS classification system. Samples for atterberg limit test was prepared using the four treatment compositions which include: $25 \% \mathrm{~B} / 75 \% \mathrm{C}, 50 \% \mathrm{~B} / 50 \% \mathrm{C}, 75 \% \mathrm{~B} / 25 \% \mathrm{C}$ and $50 \%$ of OMC B/50\% of OMC C. Results shows that LL; PL, PI and LS, recorded improvement for all the four treatment compositions. Regression analysis for the best treatment compositions (i.e $75 \% \mathrm{~B} / 25 \% \mathrm{C}$ ) has regression coefficient of $91.8 \%$.Based on the four treatment compositions considered, $75 \% \mathrm{~B} / 25 \% \mathrm{C}$ enhanced the soil workability significantly and is suggested for geotechnical engineering application. Further studies should consider the application of this treatment composition to evaluate the strength performance of lateritic soil.

\section{References}

[1] Sani J E, Afolayan J O, Chukwujama I A, Yohanna, P. Effects of Wood Saw Dust Ash Admixed with Treated Sisal Fibre on the Geotechnical Properties of Lateritic Soil. Leonardo Electronic Journal of Practice and Technology. 2017; 31: 59-76.

[2] Sani J E, Yohanna P, Chukwujama I A. Effect of Rice Husk Ash Admixed With Treated Sisal Fibre on Properties of Lateritic Soil As A Road Construction Material. Journal of King Saud University - Engineering Science. 2018. doi: https://doi.org/10.1016/j.jksues.2018.11.001.

[3] Yohanna P, Oluremi J R, Eberemu A O, Osinubi K J, Sani J E. Reliability Assessment of Bearing Capacity of Cement-Iron Ore Tailing Blend Black Cotton Soil for Strip Foundations. Journal of Geotechnical and Geological Engineering. doi.org/10.1007/s10706-018-0660-2. 2018

[4] Al-Kalili A, Ali A S, Al-Taie A J. A Review on Expansive Soils Stabilized with Different Pozzolanic Materials. Journal of Engineering. 2022; 28(1): 1-18. doi: 10.31026/j.eng.2022.01.01.

[5] Van Paassen L A. Bio-mediated ground improvement: from laboratory experiment to pilot applications. Proc. GeoFrontiers: Advances in Geotchnical Engineering, Geotechnical Special Publication. 2011; 211: 40994108.

[6] Kucharski E S, Cord-Ruwisch R, Whiffin V, Al-Thawadi S.M.J. Microbial Biocementation. World Patent. 2006; 066326.

[7] Burne R A, Chen Y Y M. Bacterial ureases in infectious diseases. Journal on Microbes and Infections. 2000; 2(5): 533-542.

[8] Muthukkumaran K B, Subramanyam S. Durability of microbial Induced Calcite Precipitation (MICP ) treated cohesionless soil. Japanese Geotechnical Society. 2006; 2(56):1946-1949. doi:10.3208/jgssp.IND-23.

[9] Volodymyr I J C. Application of microorganisms to geotechnical engineering for bioclogging and biocementation of soil insitu. Reviews in Environmental sciences and Biotechnoly. 2008; 7(2):139-153.

[10] Nemati M, Voordouw G. Modifiacation of Porous Media Permeability,using Calcium Carbonate producedenzymatically in situ. Enzyme and Microbiogy Technoloy. 2003; 33: 635-642.

[11] Choi S G, Wang K, Chu J. Properties of Biocemented, Fiber Reinforced Sand. Journal of Construction and Building Materials. 120; 2016: 623-629.

[12] Chi L, De Y, Shihui L, Tuanjie Z, Siriguleng B, Yu G, Lin L. Improvement of Geomechanical Properties of Bio-remediated Aeolian Sand. Geomicrobiology Journal. 2017; DOI: 10.1080/01490451.2017.1338798. 
[13] Osinubi K. J, Yohanna P, Eberemu A O, Ijimdiya, T S. Evaluation of hydraulic conductivity of lateritic soil treated with Bacillus coagulans for use in waste containment applications. Proceeding of the $8^{\text {th }}$ International Congress on Environmental Geotechnics. $28^{\text {th }}$ October $-1^{\text {st }}$ November, Hangzhou, China. Springer Nature Singapore Pte Ltd., 3, 401-409, On-line: 2019a; https://doi.org/10.1007/978-981-13-2227-3_50.

[14] Osinubi K J, Emmanuel W G, Adrian O E, Thomas S I, Sabo E Y. Evaluation of the Strength of Compacted Lateritic Soil Treated with Sporosarcina Pasteurii. Proceeding of the 8th International Congress on Environmental Geotechnics. 28th October - 1st November, Hangzhou, China. Springer Nature Singapore Pte Ltd.3 ,419-428, On-line: 2019b; https://doi.org/10.1007/978-981-13-2227-3_50.

[15] Osinubi K. J, John S E, Adrian O E, Thomas S I, Sabo E Y. Unconfined Compressive Strength of Bacillus Pumilus Treated Lateritic. Proceeding of the 8th International Congress on Environmental Geotechnics. $28^{\text {th }}$ Oct $-1^{\text {st }}$ Nov, Hangzhou, China. Springer Nature Singapore Pte Ltd., 3, 410-418, On-line: 2019c; https://doi.org/10.1007/978-981-13-2227-3_50.

[16] Mohammadizadeh M, Ajalloeian R, Nadi B. et al. Experimental study on soil improvement using local microorganisms. Arabian Journal of Geosciences. 2020; 13: 469. https://doi.org/10.1007/s12517-020-054503.

[17] Tiwari N, Satyam N, Sharma M. Micro-mechanical performance evaluation of expansive soil biotreated with indigenous bacteria using MICP method. Scientific Report. 2021; 11:10324. https://doi.org/10.1038/s41598021-89687-2

[18] Stocks-Fischer S, Galinat J K, Bang S S. Microbiological precipitation of $\mathrm{CaCO}_{3}$. Soil Biology and Biochem estry. 1999; 31(11): 1563-1571.

[19] ATCC. American Type Culture Collection P.O Box 1549 Manassas, VA 20108 USA. http://www.atcc.org. 2013.

[20] Rowshanbakhta K., Khamehchiyana M, Sajedib R H, Nikudela M R. Effect of Injected Bacterial Suspension Volume and Relative Density on Carbonate Precipitation Resulting from Microbial Treatment. Journal of Ecological Engineering, 2016; 89: 49-55.

[21] Mortensen B M, Haber M J, DeJong JT, Caslake L F, Nelson, D.C. Effects of environmental factors on microbial induced calcium carbonate precipitation. Journal of Applied Microbiology. 2011. doi:10.1111/j.1365-2672.2011.05065.x.

[22] Choi S G, Park S S, Wu S, Chu J. Methods for Calcium Carbonate Content Measurement of Biocemented Soils. Journal of Material in Civil Engineering. 2017; 29(11): 06017015.

[23] AASHTO. Standard Specification for Transportation, Material and Methods of Sampling and Testing. 14th Edition. Amsterdam Association of State Highway and transportation officia Washington D.C. 1986.

[24] ASTM. Annual Book of Standards. Vol. 04.08, American Society for Testing and Materials. Philadelphia. 1992.

[25] Rong H, Qian C. Microstructure evolution of sandstone cemented by microbe cement using x-ray computed tomography. Journal of Wuhan University Technology Material Science. 2013; 28(6): 1134-1139.

[26] Karim R, Mashaallah K, Reza H.S, Mohammad, R.N. Effect of injected bacterial suspension volume and relative density on carbonate precipitation resulting from microbial treatment. Journal of Ecological Engineering. 2016; 89:49-55.

[27] Sheelah E, Yosadian R. K. Effects of microorganisms on the engineering properties of cohesive soil. Geomechanics and Engineering. 2012; 4(2):135-150.

[28] Osinubi K. J, Eberemu A. O, Ijimdiya S T, Yakubu, S E, Sani J E. Potential use of B. Pumilus in microbial induced calcite precipitation improvement of lateritic soil. Proceeding of the 2nd Symposium on Couple Phenomenon in Environmental Geotechnics (CPEG2), Leeds, United Kingdom, 6 - 8 September. Session: Clean-ups, Paper \#64, Pp. 1 - 6. 2017.

[29] Kavazanjian E J, Iglesias E, Karatas I. Biopolymer soil stabilization for wind erosion control. Proceeding of the 17th International Conference of Soil Mechanics and Geotechnical Engineering, Alexandria 2, 2009: 881884.

[30] Nugent R A, Zhang G, Gambrell R P. The effect of exopolymers on the erosional resistance of cohesive sediments. Proceeding of the 5th International Conference on Soil and Erosion, San Francisco, CA, 2010:162-171.

[31] Dejong J T, Soga E, Kavazanjian S, Weaver T. Biological processes and geotechnical applications: progress, opportunities, and challenges. Geotechnique. 2013; 63(4): 28 -301.

(C) 2022 by the author(s). This work is licensed under a Creative Commons Attribution 4.0 International License (http://creativecommons.org/licenses/by/4.0/). Authors retain copyright of their work, with first publication rights granted to Tech Reviews Ltd. 